\title{
In vivo Regulation of NADP-specific Glutamate Dehydrogenase by L-Amides in Stemphylium botryosum
}

\author{
By ADINA BREIMAN AND ISAAC BARASH \\ Department of Botany, Tel Aviv University, The George S. Wise Center for Life Sciences, \\ Tel Aviv, Israel
}

(Received 31 October 1977)

\begin{abstract}
The activity of NADP-specific glutamate dehydrogenase (NADP-GDH; EC 1.4.1.4) increased at a linear rate of $2 \cdot 1 \times 10^{3}$ units $^{\mathrm{h}^{-1}}(\mathrm{~g} \text { fresh } \mathrm{wt})^{-1}$ following the transfer of Stemphylium botryosum mycelium grown in L-asparagine medium to nitrate medium. The maximum enzyme activity was reached after $5 \mathrm{~h}$. De novo synthesis was demonstrated by density labelling of the enzyme with deuterium and inhibition of NADP-GDH synthesis by cycloheximide, $p$-fluorophenylalanine or 6-methylpurine. L-Asparagine or L-glutamine could serve as a corepressor of NADP-GDH synthesis whereas the D-isomers were ineffective. Of the various amide derivatives tested, only L-asparagine tert-butyl ester could mimic the effect of L-asparagine. Enzyme repression was not correlated with the internal pool of L-amides. After NADP-GDH had been induced to the maximum level, the addition of L-asparagine and cycloheximide resulted in a decrease of activity with half-lives of $4.5 \mathrm{~h}$ and $8 \mathrm{~h}$ respectively. The mean half-life, as measured by following the decay in specific radioactivity of the enzyme in nitrate medium after administration of ${ }^{35} \mathrm{SO}_{4}{ }^{2-}$, was $7 \mathrm{~h}$. Mycelium starved of carbon and nitrogen sources showed a slow decrease (half-life of $17 \mathrm{~h}$ ) in NADP-GDH activity. Depletion of energy by carbon starvation or the presence of sodium azide did not prevent the decrease in enzyme activity caused by L-asparagine. The decrease in NADP-GDH activity mediated by L-asparagine was inhibited by cycloheximide or $\alpha$-iodoacetamide. Sodium azide inhibited the decrease in enzyme activity caused by cycloheximide.
\end{abstract}

\section{INTRODUCTION}

In contrast to the dual specificity of mammalian glutamate dehydrogenases (GDHs) for NAD and NADP, the enzymes from micro-organisms and plants exhibit preference for only one of the two coenzymes (Goldin \& Frieden, 1971). A number of fungi contain both NAD-GDH and NADP-GDH (Goldin \& Frieden, 1971; Pateman \& Kinghorn, 1975), whereas others contain only NAD-GDH (Goldin \& Frieden, 1971; Stevenson \& Le John, 1971) or NADP-GDH (Barash \& Mor, 1973). This distinct coenzyme specificity appears to be associated with two different physiological functions: the NADP-GDH being an anabolic enzyme and the NAD-GDH being a catabolic enzyme (Goldin \& Frieden, 1971). The involvement of NADP-GDH in ammonia repression of several enzymes and uptake systems has been demonstrated in Saccharomyces cerevisiae (Grenson \& Hou, 1972) and Aspergillus nidulans (Pateman \& Kinghorn, 1975).

Pateman (1969) has presented evidence for the role of L-glutamate as a corepressor of NADP-GDH synthesis in A. nidulans, Neurospora crassa and Escherichia coli. The decrease in enzyme activity during growth on ammonia and amino acids was due to indirect effects on the concentration of L-glutamate in the cells (Pateman, 1969). Repression of NADP-GDH 
by L-glutamate was also detected in other micro-organisms (Goldin \& Frieden, 1971) but was absent in germinated spores of Geotrichum candidum (Barash \& Mor, 1973), Candida utilis (Ferguson \& Sims, 1974a) and Schizophyllum commune (Dennen \& Niederpruem, 1967). Hynes (1974) showed that, in $A$. nidulans, NADP-GDH activity was rapidly lost from mycelium starved of a carbon source. Although glutamate repressed NADP-GDH synthesis, it did not cause a rapid loss in its activity (Hynes, 1974). With other fungal enzymes such as nitrate reductase (Lewis \& Fincham, 1970; Subramanian \& Sorger, 1972) and glutamine synthetase (Ferguson \& Sims, 1974b), the addition of ammonia or Lglutamine, respectively, resulted in repression of enzyme biosynthesis and a rapid and specific inactivation of the appropriate enzyme.

Most knowledge about the control of nitrogen metabolism in fungi derives from only a few species (Pateman \& Kinghorn, 1975) which are readily amenable for genetic studies. It is obvious, however, that in a large and diverse group of organisms such as fungi, considerable differences in metabolic regulation might exist. We therefore carried out experiments to investigate factors which may affect the in vivo regulation of NADP-GDH in the mycelial phytopathogenic fungus Stemphylium botryosum.

\section{METHODS}

Organism and culture conditions. A wild-type strain of Stemphylium botryosum Wallroth, pathogenic on lettuce, was used throughout these studies. Mycelium was grown in Roux bottles containing $100 \mathrm{ml}$ of liquid medium and incubated for $5 \mathrm{~d}$ at $25^{\circ} \mathrm{C}$. Growth medium (no. 1) was made in $0.1 \mathrm{M}$-potassium phosphate buffer $\mathrm{pH} 6.5$ and contained (mM): $\mathrm{MgSO}_{4}, 2 ; \mathrm{KCl}, 6.7 ; \mathrm{K}_{2} \mathrm{HPO}_{4}, 1.2 ; \mathrm{FeCl}_{3}, 0.06$; sucrose, 30; asparagine, 50; and chloramphenicol, $0 \cdot 15$. The mycelium was removed from the growth medium by suction filtration on an Ederol filter paper (no. 15) and washed several times with deionized water by successive resuspension and filtration. To stimulate NADP-GDH production, the mycelium $(0.2$ to $0.4 \mathrm{~g})$ was transferred to Erlenmeyer flasks $(100 \mathrm{ml})$ containing $20 \mathrm{ml}$ of medium no. 2. This medium was made in $0.1 \mathrm{M}$-phosphate buffer pH 6.5 and contained $(\mathrm{mM}): \mathrm{KCl}, 6.7 ; \mathrm{MgSO}_{4}, 2 ; \mathrm{KNO}_{3}, 50$; and sucrose, 15 . The flasks were incubated for $24 \mathrm{~h}$ on a reciprocal shaker ( 140 oscillations $\mathrm{min}^{-1}$ ) at $25^{\circ} \mathrm{C}$ and the mycelium was then transferred to fresh medium (no. 2) and incubated with various nitrogenous and other compounds as described in Results. After harvest, the mycelium was carefully dried by blotting with filter paper and used for fresh weight determination.

Extraction and purification procedures. Mycelium $(300 \mathrm{mg}$ fresh wt) was placed in $5 \mathrm{ml} 0 \cdot 1 \mathrm{M}$-Tris/HCl buffer, $\mathrm{pH} 8.2$, containing $1 \mathrm{~mm}-2$-mercaptoethanol and $10 \%(\mathrm{v} / \mathrm{v})$ glycerol. All the following procedures were performed at $4{ }^{\circ} \mathrm{C}$. The mycelium was disrupted for $30 \mathrm{~s}$ in a Sorval Omnimixer (model 17220) and the resulting suspension was ruptured by passage through a pre-cooled Aminco French pressure cell at $100 \mathrm{MPa}$. The cell debris was removed by centrifuging at $27000 \mathrm{~g}$ for $15 \mathrm{~min}$; the supernatant was clarified by addition of 0.025 vol. $1 \mathrm{M}-\mathrm{MnCl}_{2}$, allowed to stand for $10 \mathrm{~min}$ and then centrifuged at $15000 \mathrm{~g}$ for $10 \mathrm{~min}$. The NADP-GDH in the clarified extract was precipitated with ammonium sulphate between 60 and $80 \%$ saturation. The precipitate was dissolved in $2 \mathrm{ml} 0.05 \mathrm{M}$-Tris/HCl buffer, $\mathrm{pH} 8.2$, containing $10 \%(\mathrm{v} / \mathrm{v})$ glycerol and $1 \mathrm{~mm}$-2-mercaptoethanol, and then dialysed for $3 \mathrm{~h}$ against the same buffer. The enzyme preparation was placed on a column $(0.5 \times 7 \mathrm{~cm})$ of DEAE-cellulose (Whatman microgranular DE-52) previously equilibrated with the above buffer and the column was washed by stepwise addition of $15 \mathrm{ml}$ portions of the buffer and buffer containing $0.08 \mathrm{M}-\mathrm{KCl}$. The enzyme was then eluted with $5 \mathrm{ml}$ of similar buffer containing $0.12 \mathrm{M}-\mathrm{KCl}$. The eluted enzyme was dialysed against $0.05 \mathrm{M}$-Tris/HCl buffer, pH 8.2 , for $3 \mathrm{~h}$ with two changes of buffer. The dialysed enzyme preparation was then further purified by isopycnic equilibrium centrifugation.

The procedure for density gradient centrifugation was that of Filner \& Varner (1967). Enzyme solution, containing $10 \mu \mathrm{g}$ lactate dehydrogenase (EC 1.1.1.27, Sigma) as a marker, was uniformly mixed with $\mathrm{CsCl}$ to give a final volume of $3 \mathrm{ml}$ and a density of $1.30 \mathrm{~g} \mathrm{ml}^{-1}$. Each tube contained approximately 200 units of NADP-GDH. The tubes were centrifuged at $270000 \mathrm{~g}$ for $65 \mathrm{~h}$ at $4{ }^{\circ} \mathrm{C}$ in a Beckman model L3-50 ultracentrifuge using a SW-50.1 rotor. After centrifugation, the tubes were punctured at the bottom and two-drop fractions were collected in the cold. The refractive index of every fifth fraction was determined with a Bausch and Lomb Abbe- 32 refractometer, and the measured values were converted to density units using a standard curve. Lactate dehydrogenase activity was assayed according to the method of Kornberg (1955). Peak centres were determined from a plot on Gaussian paper (Ohno, 1961).

Disc electrophoresis on $7 \%(\mathrm{w} / \mathrm{v})$ acrylamide was performed according to Ornstein \& Davis (1962) using Tris/glycine as a tank buffer at $\mathrm{pH} 8 \cdot 3$. The current was regulated to $4 \mathrm{~mA}$ per column. The electrophoresis 
was terminated when the tracking dye, bromophenol blue, left the bottom of the column. GDH activity was detected by the tetrazolium technique (Fine \& Costello, 1963) and protein by the Coomassie brilliant blue reagent (Fazekas de St Groth, Webster \& Datyner, 1963). Scanner tracing of the gels was made using a Gilford 2410 transport scanner at $610 \mathrm{~nm}$. For measuring radioactivity, corresponding gels were cut by a Yeda macrotome (Rehovot, Israel) into $1 \mathrm{~mm}$ sections. Each section was placed in a small vial containing $0.2 \mathrm{ml} \mathrm{30} \%(\mathrm{v} / \mathrm{v}) \mathrm{H}_{2} \mathrm{O}_{2}$. The vials were incubated for $18 \mathrm{~h}$ at $60{ }^{\circ} \mathrm{C}$; then $3 \mathrm{ml}$ Packard instagel was added to each vial and radioactivity was measured with a Packard model 3375 liquid scintillation spectrometer.

Enzyme assays. GDH [EC 1.4.1.4; L-glutamate:NADP+ oxidoreductase (deaminating)] was assayed by measuring the initial rate of oxidation of NADPH at $340 \mathrm{~nm}$ in a Gilford 2400 automatic recording spectrophotometer. The reaction mixture (total volume $2 \mathrm{ml}$ ) contained (mM); Tris $/ \mathbf{H C l}, \mathrm{pH} 8 \cdot 2,100 ; \alpha-\mathrm{keto}-$ glutarate, $30 ; \mathrm{NH}_{4} \mathrm{Cl}, 50 ; \mathrm{NADPH}, 0.25 ;$ and 20 to 100 units of enzyme preparation. Malic dehydrogenase (MDH; EC 1.1.1.82; L-malate: NADP $^{+}$oxidoreductase) was measured according to Barash, Sadon \& Mor (1974). All assays were carried out at $28^{\circ} \mathrm{C}$. One unit of activity was defined as the amount of enzyme causing a change in absorbance at $340 \mathrm{~nm}$ of $0.01 \mathrm{~min}^{-1}$ under the standard assay conditions. Specific activity was calculated as units (mg protein $)^{-1}$.

Analytical procedures. For determination of amino acids and ammonia, the harvested mycelium was washed exhaustively with distilled water and immediately freeze-dried. The free amino acids were extracted twice from $50 \mathrm{mg}$ dried mycelium with $2 \mathrm{ml} 80 \%(\mathrm{v} / \mathrm{v})$ boiling ethanol for $30 \mathrm{~min}$. A sample was taken for determination of amino acids by the ninhydrin procedure (Moor \& Stein, 1948) using glutamate as a standard. A Technicon automatic amino acid analyser, with norleucine as internal standard, was used to separate and quantify individual amino acids. Ammonia was extracted twice from $50 \mathrm{mg}$ dried mycelium with $2 \mathrm{ml}$ double-distilled water at $90^{\circ} \mathrm{C}$ for $30 \mathrm{~min}$, and determined by the procedure of Buttery \& Rousell (1971). Protein was estimated by the method of Lowry et al. (1951) using crystalline bovine serum albumin as a standard.

Chemicals. $\mathrm{D}_{2} \mathrm{O}\left(99.75 \%\right.$ ), spectroscopy grade, was purchased from Merck. ${ }^{35} \mathrm{SO}_{4}{ }^{2-}$ (carrier free) was obtained from The Radiochemical Centre, Amersham. Asparagine and amino acid derivatives were obtained from Sigma. 5-Diazo-4-oxo-L-norvaline was a gift from R. E. Handschumacher, Department of Pharmacology, Yale University, U.S.A.

\section{RESULTS}

\section{Biosynthesis of NADP-GDH}

The kinetics of NADP-GDH synthesis following the transfer of mycelium grown on L-asparagine medium (no. 1) to nitrate medium (no. 2) are shown in Fig. 1. Enzyme activity increased at a linear rate of approximately $2 \cdot 1 \times 10^{3}$ units $^{-1}(\mathrm{~g} \text { fresh } \mathrm{wt})^{-1}$. The maximum activity was reached after $5 \mathrm{~h}$ and remained the same thereafter. Metabolic inhibitors such as cycloheximide, $p$-fluorophenylalanine and 6-methylpurine, at a concentration of $1 \mathrm{~mm}$, inhibited enzyme formation by $90 \%$ or more. These results suggest that synthesis of enzyme depends on protein and RNA synthesis. Additional evidence for de novo synthesis of NADP-GDH was obtained by density labelling of the enzyme. Mycelium grown in the presence of L-asparagine was incubated for $18 \mathrm{~h}$ in nitrate medium with either $70 \% \mathrm{D}_{2} \mathrm{O}$ or $\mathrm{H}_{2} \mathrm{O}$. The enzyme was then extracted and subjected to isopycnic equilibrium centrifugation as described in Methods. The enzyme from mycelium incubated with $\mathrm{D}_{2} \mathrm{O}$ had a buoyant density of $1.30 \mathrm{~g} \mathrm{ml}^{-1}$ whereas NADP-GDH from mycelium incubated with $\mathrm{H}_{2} \mathrm{O}$ had a buoyant density of $1.285 \mathrm{~g} \mathrm{ml}^{-1}$ (Fig. 2). When mycelium containing the light enzyme was incubated with $\mathrm{D}_{2} \mathrm{O}$ for $18 \mathrm{~h}$ in the presence of $10 \mathrm{mM}$-L-asparagine, no shift in the buoyant density was observed. Consequently, the possibility that deuterium exchange with pre-existing enzyme contributed to the density shift (Anstine et al., 1970) can be excluded. A single band of NADP-GDH was detected when crude or purified enzyme preparations were subjected to disc electrophoresis and specifically stained for either NAD- or NADPlinked GDHs.

\section{Repression of NADP-GDH synthesis}

Mycelium of $S$. botryosum was transferred from L-asparagine medium to nitrate medium and incubated in the presence of various nitrogen sources at concentrations ranging from 0.05 to $100 \mathrm{~mm}$. The cells were harvested after $18 \mathrm{~h}$ and their enzyme activity was determined. The results indicate that L-asparagine at a concentration as low as $1 \mathrm{~mm}$ caused about $60 \%$ 


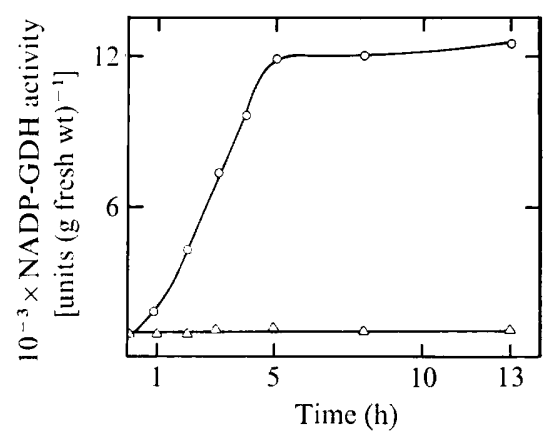

Fig. 1

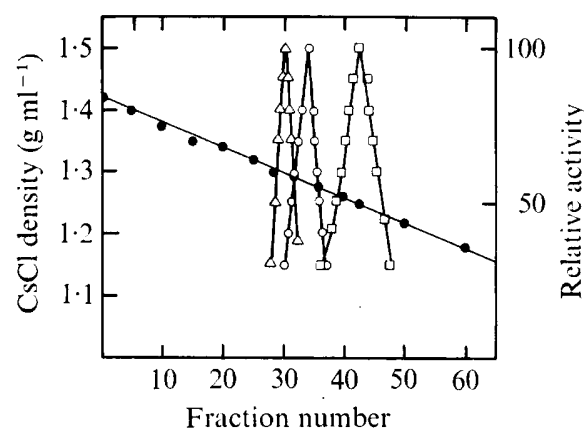

Fig. 2

Fig. 1. Kinetics of NADP-GDH synthesis in mycelium of $S$. botryosum. Mycelium grown on Lasparagine medium (no. 1) was transferred to nitrate medium (no. 2), as described in Methods, and enzyme activity and mycelium fresh weight were determined at various times. The mycelium was incubated without $(O)$ and with $(\triangle) 1 \mathrm{~mm}$-cycloheximide.

Fig. 2. Equilibrium distribution of NADP-GDH in $\mathrm{CsCl}$ gradients. Mycelium was incubated in nitrate medium (no. 2) for $18 \mathrm{~h}$ in the presence of either $70 \% \mathrm{D}_{2} \mathrm{O}(\triangle)$ or $\mathrm{H}_{2} \mathrm{O}(\mathrm{O})$. LDH $(\square)$ was used as internal marker in all tubes. The LDH activities from the various tubes were superimposed. Each curve was obtained from a separate tube. Density of $\mathrm{CsCl}(0)$.

\section{Table 1. Effects of isomers or structural derivatives of asparagine and glutamine on repression of $N A D P-G D H$}

Mycelium was incubated for $18 \mathrm{~h}$ in the presence of various analogues under the conditions described in the legend to Fig. 1.

\begin{tabular}{clc} 
Structure type & \multicolumn{1}{c}{$\begin{array}{c}\text { Addition }(10 \mathrm{mM}) \\
\text { Repression of } \\
\text { NADP-GDH } \\
(\%)^{*}\end{array}$} \\
& L-Asparagine & 90 \\
& L-Glutamine & 90 \\
& D-Asparagine & 0 \\
$\beta$ - or $\gamma$-Carboxyl derivative & 5-Diazo-4-oxo-L-norvaline & 0 \\
& $\beta$-Aspartyl hydroxamate & 23 \\
$\alpha$-Amino derivatives & $\gamma$-Glutamyl hydroxamate & 39 \\
& $N$-Acetylasparagine & 20 \\
$\alpha$-Carboxyl derivative & $N$-Acetylglutamine & 0 \\
* The mean NADP-GDH activity of the control was $(120 \pm 5) \times 10^{2}$ units $\left(\mathrm{g}\right.$ fresh wt) ${ }^{-1}$.
\end{tabular}

repression of enzyme synthesis whereas $94 \%$ repression was obtained with $10 \mathrm{mM}$-L-asparagine (Fig. 3). L-Glutamine showed a similar effect. L-Glutamate, L-aspartate and $\mathrm{NH}_{4} \mathrm{Cl}$ showed an effective repression only at very high concentrations $(100 \mathrm{mM})$. The effect of various derivatives and isomers of asparagine or glutamine on inhibition of enzyme induction is shown in Table 1. After L-asparagine and L-glutamine, L-asparagine tert-butyl ester was the most effective corepressor. Hydroxamates of glutamine and asparagine caused moderate inhibition whereas other derivatives had little or no effect on enzyme synthesis.

To gain more insight into the nature of the repression process, the effects of nitrate, $\mathrm{NH}_{4}{ }^{+}$and L-amides on the content of the amino acid pools were studied (Table 2). The amounts of total amino acids and of ammonia increased up to 3.6-fold when a nitrogen source $(5 \mathrm{~mm})$ was added to nitrogen-starved mycelium. The concentration of free amino acids in the presence of external $\mathrm{NH}_{4}{ }^{+}$or amides $(5 \mathrm{mM})$ was at least twice that in the presence of nitrate. The pools of L-glutamate, L-alanine and L-glutamine showed marked changes in response to nitrogen supply. It is noteworthy that the amount of endogenous glutamine was higher in mycelium incubated with $\mathrm{NH}_{4}+$ than in the presence of the L-amides. Significant 
Table 2. Effect of different nitrogen sources on the pools of amino acids and $\mathrm{NH}_{4}{ }^{+}$

\begin{tabular}{|c|c|c|c|c|c|c|c|c|c|}
\hline \multirow{3}{*}{$\begin{array}{c}\text { Amino acids } \\
\text { or } \mathrm{NH}_{4}^{+} \\
\left.[\mu \mathrm{mol} \mathrm{(g} \mathrm{dry} \mathrm{wt})^{-1}\right]\end{array}$} & \multirow{3}{*}{$\begin{array}{l}\text { Nitrogen- } \\
\text { starved } \\
\text { mycel- } \\
\text { ium* }\end{array}$} & \multicolumn{8}{|c|}{ Nitrogen source added $(\mathrm{mm}) \dagger$} \\
\hline & & \multicolumn{2}{|c|}{$\mathrm{KNO}_{3}$} & \multicolumn{2}{|c|}{$\mathrm{NH}_{4} \mathrm{Cl}$} & \multicolumn{2}{|c|}{ Asparagine } & \multicolumn{2}{|c|}{ Glutamine } \\
\hline & & $0 \cdot 1$ & 5 & $0 \cdot 1$ & 5 & $0 \cdot 1$ & 5 & $0 \cdot 1$ & 5 \\
\hline $\begin{array}{l}\text { Aspartate } \\
\text { Asparagine } \\
\text { Glutamate } \\
\text { Glutamine } \\
\text { Alanine } \\
\gamma \text {-Aminobutyric } \\
\text { acid }\end{array}$ & $\begin{array}{r}1 \cdot 73 \\
1 \cdot 27 \\
9 \cdot 17 \\
2 \cdot 12 \\
21 \cdot 12 \\
16 \cdot 69\end{array}$ & $\begin{array}{r}1 \cdot 8 \\
1 \cdot 5 \\
18 \cdot 5 \\
4 \cdot 5 \\
21 \cdot 1 \\
13 \cdot 8\end{array}$ & $\begin{array}{r}3 \cdot 1 \\
1 \cdot 7 \\
29 \cdot 5 \\
5 \cdot 2 \\
30 \cdot 9 \\
16 \cdot 2\end{array}$ & $\begin{array}{r}5 \cdot 5 \\
6 \cdot 1 \\
30 \cdot 2 \\
4 \cdot 7 \\
29 \cdot 7 \\
17 \cdot 7\end{array}$ & $\begin{array}{r}4 \cdot 0 \\
3 \cdot 4 \\
80 \cdot 1 \\
36 \cdot 9 \\
110 \cdot 1 \\
20 \cdot 5\end{array}$ & $\begin{array}{l}55 \cdot 3 \\
10 \cdot 0 \\
52 \cdot 8 \\
21 \cdot 4\end{array}$ & $\begin{array}{r}43 \cdot 0 \\
92 \cdot 2 \\
52 \cdot 0 \\
9 \cdot 4 \\
48 \cdot 4 \\
19 \cdot 1\end{array}$ & $\begin{array}{r}2 \cdot 4 \\
1 \cdot 6 \\
27 \cdot 0 \\
6 \cdot 7 \\
25 \cdot 8 \\
18 \cdot 4\end{array}$ & $\begin{array}{r}3 \cdot 4 \\
2 \cdot 0 \\
74 \cdot 7 \\
25 \cdot 7 \\
43 \cdot 0 \\
22 \cdot 1\end{array}$ \\
\hline $\begin{array}{l}\text { Lysine } \\
\text { Arginine }\end{array}$ & $\begin{array}{l}1.98 \\
5.90\end{array}$ & $\begin{array}{l}2.0 \\
5.0\end{array}$ & $\begin{array}{l}2 \cdot 6 \\
8 \cdot 0\end{array}$ & $\begin{array}{l}2.5 \\
6.9\end{array}$ & $\begin{array}{r}3 \cdot 3 \\
10 \cdot 3\end{array}$ & $\begin{array}{r}3 \cdot 4 \\
10 \cdot 8\end{array}$ & $\begin{array}{r}3 \cdot 5 \\
14 \cdot 3\end{array}$ & $\begin{array}{l}2.25 \\
8.9\end{array}$ & $\begin{array}{l}2 \cdot 8 \\
9 \cdot 3\end{array}$ \\
\hline $\begin{array}{l}\text { Total amino } \\
\text { acids } \ddagger\end{array}$ & $85 \cdot 70$ & $85 \cdot 5$ & 128 & 135 & 293 & 204 & 314 & 118 & 221 \\
\hline $\mathrm{NH}_{4}{ }^{+}$ & $9 \cdot 20$ & $9 \cdot 7$ & 13.5 & $11 \cdot 4$ & $20 \cdot 7$ & $12 \cdot 5$ & $17 \cdot 1$ & $12 \cdot 7$ & $22 \cdot 3$ \\
\hline
\end{tabular}

* Mycelium was incubated on a shaker at $25^{\circ} \mathrm{C}$ for $2 \mathrm{~h}$ in the presence of sucrose.

+ Nitrogen sources were added to nitrogen-starved mycelium and incubated for $1 \mathrm{~h}$.

Includes additional amino acids which are not given in the Table.

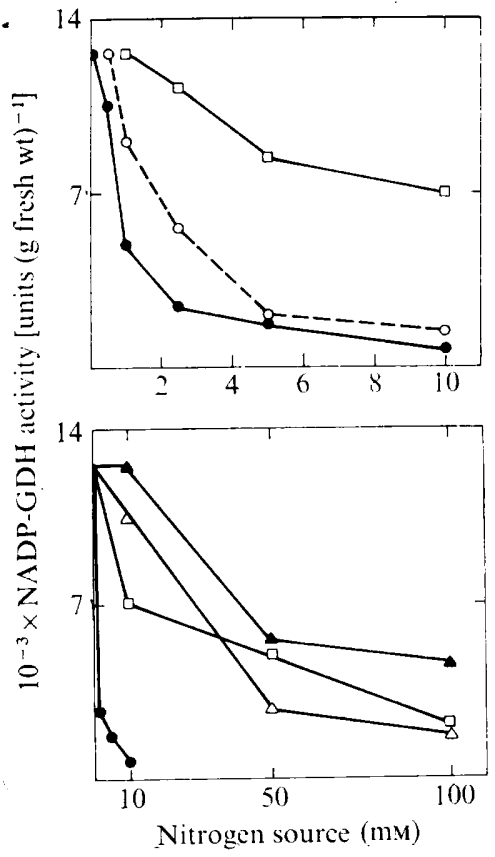

Fig. 3

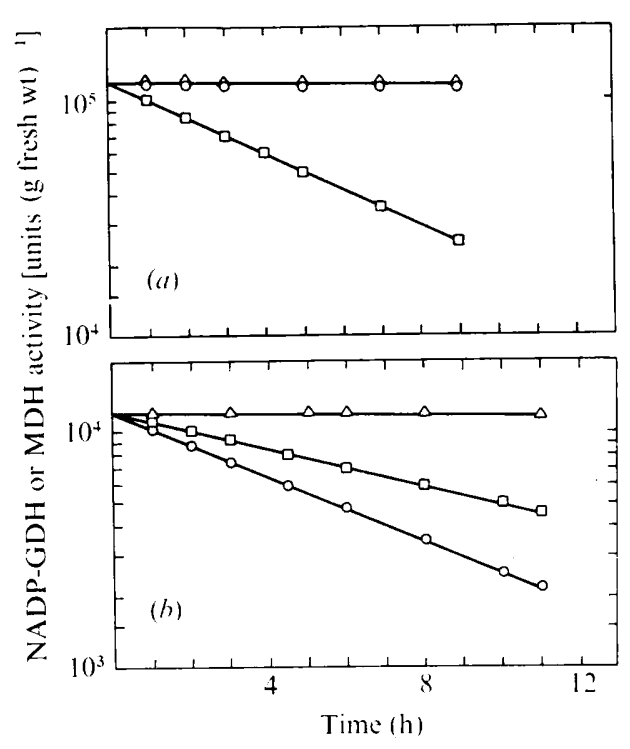

Fig. 4

Fig. 3. Activity of NADP-GDH in mycelium incubated with various concentrations and types of nitrogen source: $\bullet$, L-asparagine; $O$, L-glutamine; $\square$, L-glutamate; $\triangle, \mathrm{NH}_{4} \mathrm{Cl}$; $\Delta$, L-aspartate. Mycelium was incubated for $18 \mathrm{~h}$ under the conditions described in the legend to Fig. 1.

Fig. 4. Effects of L-asparagine and cycloheximide on the stability of $(a) \mathrm{MDH}$ and $(b)$ NADP-GDH in mycelium. Mycelium was pre-incubated for $18 \mathrm{~h}$ in nitrate medium (no. 2) before the addition of either $10 \mathrm{~mm}$-L-asparagine $(\bigcirc)$ or $1 \mathrm{~mm}$-cycloheximide $(\square)$. Activity in nitrate medium $(\triangle)$. 


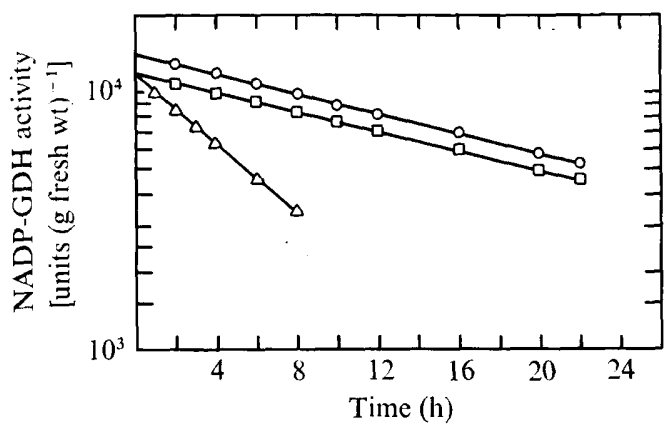

Fig. 5

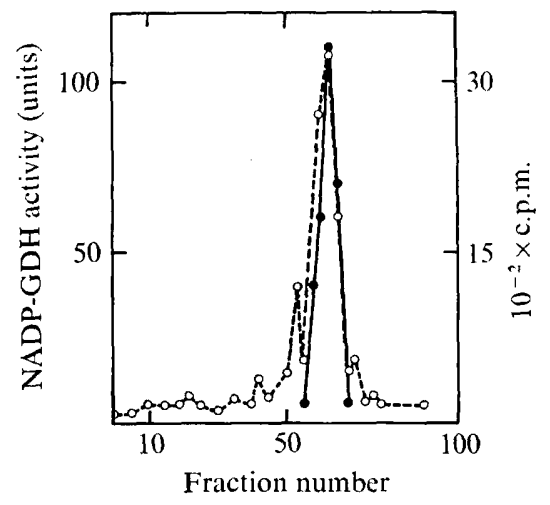

Fig. 6

Fig. 5. Effect of starvation on the stability of NADP-GDH and MDH in mycelium. Mycelium was pre-incubated for $18 \mathrm{~h}$ in nitrate medium (no. 2), washed with $0 \cdot 1 \mathrm{M}$-phosphate buffer pH $6 \cdot 5$, and transferred to the same buffer for further incubation. Activities of MDH ( $\square$ ), NADP-GDH (O) and NADP-GDH in the presence of $10 \mathrm{~mm}$-L-asparagine $(\triangle)$ were measured at various times.

Fig. 6. Equilibrium distribution of purified radioactive NADP-GDH in a $\mathrm{CsCl}$ gradient. Enzyme preparation (200 units) from the DEAE-cellulose column was applied to each tube and purified as described in Methods. Alternate fractions were used for measuring NADP-GDH activity (O) and radioactivity $(O)$ respectively.

amounts of L-asparagine and L-glutamine which effectively repress NADP-GDH synthesis (Fig. 3) were always present in the soluble pool (Table 2). No correlation could be detected between the pool sizes of the L-amides and enzyme repression.

\section{Effect of L-amides on the stability of NADP-GDH in vivo}

When L-asparagine was added to mycelium grown in nitrate medium, NADP-GDH activity declined rapidly whereas MDH activity remained unchanged (Fig. 4). The fall in NADP-GDH activity followed a first-order rate equation with a half-life of $4.5 \mathrm{~h}$. Similar results were obtained when L-asparagine was replaced by L-glutamine. Addition of cycloheximide which effectively prevented NADP-GDH synthesis (Fig. 1), reduced the activity of both NADP-GDH and MDH. However, the half-life of NADP-GDH was considerably higher in the presence of cycloheximide $(8 \mathrm{~h})$ than with L-asparagine $(4.5 \mathrm{~h})$. Neither L-asparagine nor cycloheximide exhibited any effect on NADP-GDH activity in vitro.

The effect of starving mycelium of external sugars on the stability of NADP-GDH is shown in Fig. 5. Mycelium starved of nitrogen and carbon sources showed a slow decrease in NADP-GDH activity. Similar results were obtained by the removal of carbon source alone. However, sugars were not required for the effect of L-asparagine on NADP-GDH activity (Fig. 5).

\section{Effect of metabolic inhibitors on the stability of NADP-GDH in vivo}

The influence of metabolic inhibitors on NADP-GDH activity under various conditions is illustrated in Table 3 . Addition of sodium azide completely prevented the decrease in enzyme activity caused by cycloheximide but did not prevent the decrease caused by $\mathrm{L}$-asparagine. However, addition of $\alpha$-iodoacetamide did not prevent the decrease in enzyme activity caused by cycloheximide, but did affect the decrease due to L-asparagine. The latter conclusion is based on the observation that $\alpha$-iodoacetamide caused 55 to $60 \%$ loss of NADP-GDH activity in either the presence or absence of L-asparagine as compared to $92 \%$ loss caused by L-asparagine alone (Table 3 ). Enzyme activity retained with both cycloheximide and L-asparagine was higher than in the presence of the individual compounds. 


\section{Table 3. Effect of various metabolic inhibitors on NADP-GDH activity}

Mycelium was pre-incubated for $18 \mathrm{~h}$ in nitrate medium (no. 2) to attain maximum enzyme activity before being transferred to the indicated media. The enzyme activity $\left(\mathrm{g}\right.$ fresh wt) ${ }^{-1}$ was determined after additional incubation for $24 \mathrm{~h}$.

\begin{tabular}{|c|c|c|c|}
\hline & NADP-G & $\begin{array}{l}\mathrm{H} \text { activity }(\% \\
\mathrm{r} \text { incubation } \mathrm{i}\end{array}$ & $\begin{array}{l}\text { f control) } \\
\text { : }\end{array}$ \\
\hline Addition (1 mM) & $\begin{array}{l}\text { Nitrate } \\
\text { medium }\end{array}$ & $\begin{array}{c}\text { Nitrate } \\
\text { medium }+ \\
\text { L-asparagine } \\
(10 \mathrm{~mm})\end{array}$ & $\begin{array}{l}\text { Nitrate } \\
\text { medium } \\
\text { cyclo- } \\
\text { heximide } \\
(1 \mathrm{~mm})\end{array}$ \\
\hline None & $100^{*}$ & 8 & 20 \\
\hline Azide & 90 & 17 & 90 \\
\hline Arsenate & 90 & 25 & 10 \\
\hline$\alpha$-lodoacetamide & 45 & 40 & 12 \\
\hline Cycloheximide & - & 38 & - \\
\hline
\end{tabular}

* Represents NADP-GDH activity of $(120 \pm 5) \times 10^{2}$ units $(\mathrm{g} \text { fresh wt })^{-1}$.

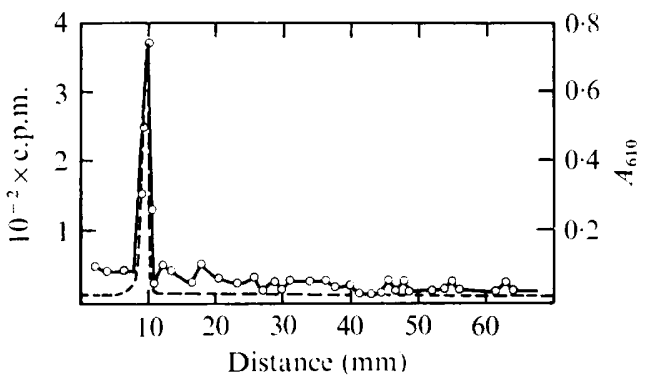

Fig. 7

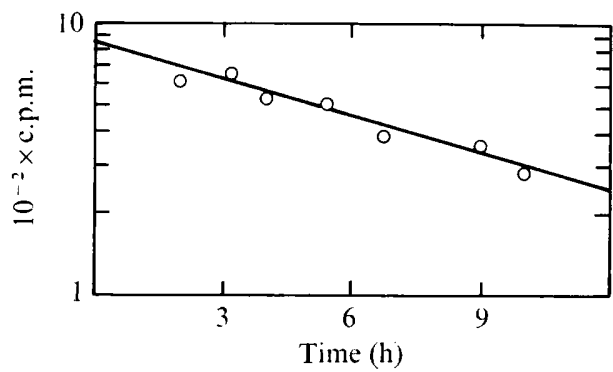

Fig. 8

Fig. 7. Electrophoretic separation pattern of NADP-GDH following isopycnic equilibrium centrifugation. Approximately $20 \mu \mathrm{g}$ protein and 4 enzyme units respectively were placed on corresponding gels for detection of radioactivity $(O)$ and enzyme activity (---).

Fig. 8. Loss of radioactivity from NADP-GDH during incubation of mycelium in nitrate medium. Experimental conditions were as described in Methods.

\section{Determination of the half-life of NADP-GDH by an isotopic technique}

The half-lives obtained by measuring the loss in enzyme activity (Fig. 4) are based on inhibition of NADP-GDH synthesis by L-asparagine and cycloheximide respectively. However, these chemicals could have stimulatory or inhibitory effects on enzyme degradation or inactivation. To determine the half-life of the enzyme in the absence of both L-asparagine and cycloheximide, mycelium grown in L-asparagine medium (no. 1) was transferred to nitrate medium (no. 2) containing $\mathrm{MgCl}_{2}$ instead of $\mathrm{MgSO}_{4}$. The cells were adapted to nitrate medium in the presence of $10 \mu \mathrm{Ci}^{35} \mathrm{SO}_{4}{ }^{2-}$ per $20 \mathrm{ml}$ culture under conditions described in Methods. After $24 \mathrm{~h}$ incubation, the radioactive sulphate was removed by rinsing the mycelium with nitrate medium containing $\mathrm{MgSO}_{4}$ and further incubated in the same medium. Samples of mycelium $(0.3$ to $0.4 \mathrm{~g}$ fresh $\mathrm{wt})$ were harvested at various times, frozen and stored at $-15^{\circ} \mathrm{C}$, until used for enzyme isolation. NADP-GDH was purified by the procedure described in Methods. The distribution of enzyme activity and radioactivity after density gradient centrifugation is shown in Fig. 6 . The ratio of enzyme activity to radioactivity is not constant throughout the peak suggesting that the enzyme is not radiochemically pure. Therefore, the peak fraction alone was used for determination of the radioactivity. The purity of the enzyme in the peak fraction was tested by disc electro- 
phoresis. Corresponding gels were used for detection of radioactivity, enzyme activity and protein, respectively, as described in Methods. The distribution pattern of radioactivity and enzyme activity in the acrylamide gel (Fig. 7) indicates that NADP-GDH was the only radioactive protein in the purified enzyme preparation. NADP-GDH was also the major protein band which could be detected by Coomassie brilliant blue staining. Two other protein bands appeared in trace amounts and did not contain radioactivity. After the centrifugation step, the specific activity of NADP-GDH was $12 \cdot 6 \times 10^{3}$ units (mg protein) ${ }^{-1}$, an 83-fold purification of the crude enzyme preparation. The mean half-life obtained by following the loss of radioactivity from ${ }^{35} \mathrm{~S}$-labelled enzyme was $7 \mathrm{~h}$ (Fig. 8).

\section{DISCUSSION}

Maximum synthesis of NADP-GDH in S. botryosum occurred in nitrate medium and was accompanied by a decrease in the pools of amino acids. Enzyme synthesis was repressed in media containing high concentrations of $\mathrm{NH}_{4}{ }^{+}$or amino acids. These observations are in accordance with the biosynthetic role assigned to NADP-GDH in other fungi (Goldin \& Frieden, 1971). L-Glutamate serves as a corepressor of NADP-GDH in various fungi and bacteria (Pateman, 1969; Le John, Suzuki \& Wright, 1968; Goldin \& Frieden, 1971). Since the external concentration $(5 \mathrm{mM})$ of L-asparagine or L-glutamine required to achieve $90 \%$ repression was at least 20 times lower than that of $\mathrm{NH}_{4}{ }^{+}$, L-glutamate or any other amino acid, it is reasonable to consider the L-amides rather than L-glutamate as corepressors of NADP-GDH in $S$. botryosum. L-Glutamine has been established as a corepressor of glutamine synthetase in Candida utilis (Ferguson \& Sims, 1974a) and other fungi (Pateman, 1969) and an inducer of NADP-GDH in the higher plant Lemna minor (Rhodes, Rendon \& Stewart, 1976). However, to the best of our knowledge, L-amides have not been directly implicated in repression of NADP-GDH synthesis.

The variation in NADP-GDH activity with different external nitrogen sources was not reflected by changes in the L-amide pool concentrations. Thus, although external $\mathrm{NH}_{4}{ }^{+}$ $(5 \mathrm{~mm})$ and L-glutamine ( $5 \mathrm{~mm}$ ) repressed enzyme synthesis by approximately $30 \%$ and $90 \%$, respectively, the amount of intracellular L-amides in the presence of $\mathrm{NH}_{4}{ }^{+}$was higher than with glutamine. Furthermore, the L-glutamine pool concentration in the presence of $\mathrm{NH}_{4}{ }^{+}$was approximately $9 \mathrm{mM}$, an amount which would be expected to cause $90 \%$ repression of NADP-GDH synthesis if given externally to the cells. The simplest hypothesis to explain the discrepancy between the effects of externally transported and internally synthesized L-amides on enzyme repression is that the L-amides are not distributed homogeneously within the fungal cells. Evidence for compartmentation of amino acids in fungi has been presented by Pateman \& Kinghorn (1975). It can be postulated that the transport and channelling of L-amides to the repression site of NADP-GDH is much faster from the extracellular medium than from the intracellular pools. Such a difference in transport rates allows the cells to respond rapidly to changes in the external environment without depleting the L-amides which are vital for normal metabolism. It is noteworthy that the L-asparagine and L-glutamine enter the mycelium of $S$. botryosum by means of a common permease system (Breiman \& Barash, 1976) which might be linked to the channelling of these metabolites to the repression site. Repression of enzyme by asparagine appears to be highly specific for the L-form.

Starvation or removal of the carbon source from cultures of $S$. botryosum slowed down the disappearance of NADP-GDH. In contrast, removal of the carbon source from $A$. nidulans resulted in a rapid loss of NADP-GDH activity (Hynes, 1974). L-Glutamate, which is a corepressor of this enzyme in the latter fungus, did not have any effect on enzyme disappearance in the presence of glucose. In contrast to A. nidulans, the inactivating or degrading system for NADP-GDH which was detected in $S$. botryosum by addition of L-asparagine was independent of glucose. The half-life for the decrease in NADP-GDH 
activity in the presence of L-asparagine was $4.5 \mathrm{~h}$ whereas the half-life as determined by the isotopic technique was $7 \mathrm{~h}$. The difference between the two values could imply that Lasparagine stimulates enzyme degradation or inactivation. However, in view of the complications involved in accurately measuring the rate constant of protein degradation by the isotopic method (Glass \& Doyle, 1972; Huffaker \& Peterson, 1974), the latter possibility should be taken with reservation. The disappearance of NADP-GDH was significantly slower in the presence of cycloheximide than with L-asparagine, suggesting that protein synthesis is involved in the inactivation or degradation of the enzyme. The latter point is further supported by the inhibitory effect of cycloheximide on the loss of NADP-GDH activity caused by L-asparagine. The various effects of the inhibitors on NADP-GDH are complex and may not lead to any simple interpretation. It is, however, noteworthy that azide selectively inhibited NADP-GDH disappearance due to cycloheximide but not that due to $\mathrm{L}$-asparagine whereas $\alpha$-iodoacetamide inhibited the $\mathrm{L}$-asparagine effect. Therefore, the possibility that L-asparagine induces a specific mechanism for degradation or inactivation of NADP-GDH in $S$. botryosum cannot be excluded.

This work is part of a Ph.D. thesis submitted to Tel Aviv University by the senior author

\section{REFERENCES}

Anstine, W., Jacobson, J. V., Scandalios, J. G. \& VARNER, J. E. (1970). Deuterium oxide as a density label of peroxides in germinating barley embryos. Plant Physiology 45, 148-152.

BARASH, I. \& MOR, H. (1973). Regulation of nicotinamide adenine dinucleotide phosphate-specific glutamate dehydrogenase in germinated spores of Geotrichum candidum. Plant Physiology 51, 852858.

Barash, I., SAdON, T. \& Mor, H. (1974). Relationship of glutamate dehydrogenase levels to free amino acids, amides and ammonia in excised oat leaves. Plant and Cell Physiology 15, 563-566.

Breiman, A. \& Barash, I. (1976). Characterization of L-asparagine transport systems in Stemphylium botryosum. Journal of Bacteriology 127, 1127-1135.

ButTery, P. J. \& Roứlel, E. V. (1971). Enzymatic assays for ammonia and L-glutamate in tissue extracts. Analytical Biochemistry 39, 297-310.

DenNen, D. W. \& NiederPRUEM, O. J. (1967). Regulation of glutamate dehydrogenase during morphogenesis of Schizophyllum commune. Journal of Bacteriology 93, 913-918.

Fazekas de St Groth, S., Webster, R. G. \& DATYNER, A. (1963). Two new staining procedures for the quantitative estimation of proteins on electrophoretic strips. Biochimica et biophysica acta 71, 377-391.

Ferguson, A. R. \& Sims, A. P. (1974a). The regulation of glutamine metabolism in Candida utilis: the role of glutamine in the control of glutamine synthetase. Journal of General Microbiology 80, 159-171.

Ferguson, A. R. \& Sims, A. P. (1974b). The regulation of glutamine metabolism in Candida utilis: the inactivation of glutamine synthetase. Journal of General Microbiology 80, 173-185.

Filner, P. \& VARner, J. E. (1967). A test for de novo synthesis of enzymes: density labeling with $\mathrm{H}_{2} \mathrm{O}^{18}$ of barley amylase induced by gibberellic acid.
Proceedings of the National Academy of Sciences of the United States of America 58, 1520-1526.

Fine, I. H. \& Costello, L. A. (1963). The use of starch electrophoresis in dehydrogenase studies. Methods in Enzymology 6, 958-972.

Glass, R. D. \& DoYle, D. (1972). On the measurement of protein turnover in animal cells. Journal of Biological Chemistry 16, 5234-5242.

GoldIN, B. R. \& FrIEDEN, C. (1971). L-Glutamate dehydrogenases. Current Topics in Cellular Regulation 4, 77-117.

GrENSON, M. \& Hou, C. (1972). Ammonia inhibition of the general amino acid permease and its suppression in NADP-specific glutamate dehydrogenaseless mutants of Saccharomyces cerevisiae. Biochemical and Biophysical Research Communications 48, 749-756.

Huffaker, R. C. \& Peterson, L. W. (1974). Protein turnover in plants and possible means of its regulation. Annual Review of Plant Physiology 25, 363-392.

HyNES, M. J. (1974). The effects of the carbon source on glutamate dehydrogenase activities in Aspergillus nidulans. Journal of General Microbiology 81, 165-170.

KORNBERG, A. (1955). Lactic dehydrogenase of muscle. Methods in Enzymology 1, 441-443.

Le John, M. G., Suzuki, I. \& Wright, J. A. (1968). Glutamate dehydrogenases of Thiobacillus novellus. Journal of Biological Chemistry 243, 118-128.

Lewis, C. M. \& Fincham, J. R. S. (1970). Regulation of nitrate reductase in the basidiomycete Ustilago maydis. Journal of Bacteriology 103, 55-61.

Lowry, O. H., Rosebrough, N. J., FARR, A. L. \& RaNDALl, R. J. (1951). Protein measurements with the Folin phenol reagent. Journal of Biological Chemistry 193, 265-275.

Moor, S. \& SteIN, W. W. (1948). Photometric ninhydrin method for use in the chromatography 
of amino acids. Journal of Biological Chemistry 176, 367-388.

OHNo, P. (1961). New graph paper for the analysis of Gaussian distribution. Review of Scientific Instruments 39, 1253-1255.

OrnsteIn, L. \& Davis, D. J. (1962). Disc Electrophoresis. Rochester, New York: Distillation Products Industries.

Pateman, J. A. (1969). Regulation of synthesis of glutamate dehydrogenase and glutamine synthetase in microorganisms. Biochemical Journal 115, 769-775.

Pateman, J. A. \& Kinghorn, J. R. (1975). Nitrogen metabolism. In The Filamentous Fungi, vol. 2, pp. 159-237. Edited by J. E. Smith \& D. Berry. London: Edward Arnold.

Rhodes, D., Rendon, G. A., Stewart, G. R. (1976). The regulation of ammonia assimilating enzymes in Lemna minor. Planta 129, 203-210.

Stevenson, R. M. \& Le JohN, M. B. (1971). Glutamic dehydrogenase of Oomycetes. Journal of Biological Chemistry 246, 2127-2135.

Subramanian, K. M. \& Sorger, G. J. (1972). Regulation of nitrate reductase in Neurospora crassa: stability in vivo. Journal of Bacteriology 110, 538-546. 